\title{
Acaricide resistance mechanisms in Rhipicephalus (Boophilus) microplus
}

\author{
Mecanismos de resistência aos acaricidas em Rhipicephalus (Boophilus) microplus \\ Felix David Guerrero ${ }^{1 *}$; Léonore Lovis ${ }^{2}$; João Ricardo Martins ${ }^{3}$ \\ ${ }^{1}$ Knipling-Bushland U.S. Livestock Insects Research Lab - KBUSLIRL, United States Department of Agriculture - USDA-ARS \\ ${ }^{2}$ Laboratory of Parasitology, University of Neuchâtel - UniNE \\ ${ }^{3}$ Laboratory of Parasitology, Instituto de Pesquisa Veterinárias Desidério Finamor - IPVDF, \\ Fundação Estadual de Pesquisa Agropecuária - FEPAGRO
}

Received February 12, 2012

Accepted March 5, 2012

\begin{abstract}
Acaricide resistance has become widespread in countries where cattle ticks, Rhipicephalus (Boophilus) microplus, are a problem. Resistance arises through genetic changes in a cattle tick population that causes modifications to the target site, increased metabolism or sequestration of the acaricide, or reduced ability of the acaricide to penetrate through the outer protective layers of the tick's body. We review the molecular and biochemical mechanisms of acaricide resistance that have been shown to be functional in $R$. (B.) microplus. From a mechanistic point of view, resistance to pyrethroids has been characterized to a greater degree than any other acaricide class. Although a great deal of research has gone into discovery of the mechanisms that cause organophosphate resistance, very little is defined at the molecular level and organophosphate resistance seems to be maintained through a complex and multifactorial process. The resistance mechanisms for other acaricides are less well understood. The target sites of fipronil and the macrocyclic lactones are known and resistance mechanism studies are in the early stages. The target site of amitraz has not been definitively identified and this is hampering mechanistic studies on this acaricide.
\end{abstract}

Keywords: Cattle tick, resistance mechanisms, target site mutation, metabolism.

\section{Resumo}

A resistência aos acaricidas tornou-se amplamente difundida nos países onde os carrapatos bovinos, Rhipicephalus (Boophilus) microplus, são um problema. A resistência surge por meio de alteraçóes genéticas em uma população de carrapatos que causam modificaçóes no local de ação, aumento do metabolismo ou sequestro do acaricida, ou ainda redução na capacidade do acaricida em penetrar através das camadas protetoras do corpo do carrapato. Neste artigo, foram revisados os mecanismos moleculares e bioquímicos da resistência aos acaricidas que ocorrem em $R$. (B.) microplus. A partir de um ponto de vista dos mecanismos envolvidos, a resistência aos piretróides tem sido caracterizada em maior grau do que em qualquer outra classe de acaricida. Embora uma grande quantidade de pesquisas têm sido direcionada para a descoberta de mecanismos que causam resistência aos organofosforados, muito pouco é conhecido ao nível molecular, e essa resistência parece ser mantida por intermédio de um processo multifatorial e complexo. Os mecanismos de resistência para os demais acaricidas são bem menos compreendidos. Os alvos de ação do fipronil e das lactonas macrocíclicas são conhecidos, e os estudos dos mecanismos de ação envolvidos estão ainda em estágios iniciais. $\mathrm{O}$ alvo de ação do amitraz ainda não foi definitivamente identificado, e isso é limitante aos estudos dos mecanismos envolvidos na resistência a esse acaricida.

Palavras-chave: Carrapato bovino, mecanismos de resistência, mutação no local de ação, metabolismo.

\footnotetext{
*Corresponding author: Felix David Guerrero

Knipling-Bushland U.S. Livestock Insects Research Lab - KBUSLIRL,

United States Department of Agriculture - USDA-ARS, 2700,

Fredericksburg Rd., 78006, Kerrville, TX, United States of America

e-mail: felix.guerrero@ars.usda.gov
} 


\section{Introduction}

McKosker (1979) estimated the global costs of ticks and tick-borne diseases to agriculture was over $\$ 7$ billion. Although this was a crude estimate using broad assumptions, there is no doubt that ticks have a great impact on agricultural productivity and tick control is a necessary part of cattle production. The identification of chemicals with acaricidal properties quickly led to the adoption of chemical acaricides as the predominant method of tick control throughout the world. The cattle tick, Rhipicephalus (Boophilus) microplus, presents a challenge to cattle producers, as its life cycle and broad distribution through the tropical and subtropical regions of the world present conditions optimal for the rapid development of acaricide resistance.

In general terms, resistance can arise through several mechanisms in individual cattle ticks. Generally these mechanisms are broadly classified as target site, metabolic, or reduced penetration. Penetration resistance in ticks could arise through alterations in the ability of an acaricide to penetrate or otherwise enter an individual that is treated with acaricide. Although this resistance mechanism has been identified in a few arthropods (NOPPUN et al., 1989), including $R$. (B.) microplus (SCHNITZERLING et al., 1983), investigations into this mechanism in the cattle tick have not been reported recently. Target site resistance exists when an allele of the gene coding for the target molecule attacked by the acaricide has an amino acid mutation that confers resistance to the acaricide. This resistance mechanism is common, particularly well-studied in the case of pyrethroid class of acaricides, and will be discussed extensively below. Metabolic resistance to acaricides occurs through changes in the ability of an individual to detoxify or sequester an acaricide. The enzyme families known as cytochrome P450s, esterases, and glutathione $\mathrm{S}$-transferases are generally involved in metabolic resistance and this type of resistance has been studied in $R$. (B.) microplus and will be discussed below. Often chemicals known as synergists are utilized to help discern resistance mechanisms in cattle ticks through bioassays. Synergist studies are especially helpful to detect metabolic resistance and common synergists are piperonyl butoxide (PBO), triphenyl phosphate (TPP) and diethylmaleate (DEM), which are generally believed to be specific for the cytochrome P450s, carboxylesterases, and glutathione S-transferases, respectively. However, the effects of synergists are not gene family-specific, as demonstrated by Young et al. (2005) who reported PBO effected pyrethroid resistance-associated esterases, and these studies must be interpreted with care.

\section{Pyrethroid Resistance}

The voltage-gated sodium channel is the target site for pyrethroid activity and target site resistance to pyrethroids has been studied in many arthropod species. An early report of target site-based resistance in $R$. (B.) microplus was Miller et al. (1999) working with pyrethroid resistant tick populations from Mexico. Their work was verified by He et al. (1999) who used gene sequencing to discover a specific amino acid substitution in Domain III (phenylalanine to isoleucine) of the $R$. (B.) microplus sodium channel in those Mexican tick populations. A PCR diagnostic assay (GUERRERO et al., 2001) was developed that allowed the rapid detection of this amino acid substitution in individual ticks, larvae or eggs. Large numbers of ticks were assayed by this method and this target site mechanism was found to be widespread throughout Mexico (ROSARIO-CRUZ et al., 2005, 2009) and in an outbreak strain in the United States (MILLER et al., 2007). The location of this sodium channel mutation is a bit out of the ordinary, as more arthropod sodium channel pyrethroid resistance-causing mutations are located in Domain II than the other three domains (SODERLUND; KNIPPLE, 2003). Interestingly, a survey of three pyrethroid resistant $R$. (B.) microplus populations from Mato Grosso do Sul, Brazil did not find this sodium channel mutation (ANDREOTTI et al., 2011). Our own survey, although limited in scope, also has not found the Domain III sodium channel mutation in either Brazilian or Australian tick populations (Table 1). However, recently Morgan et al. (2009) and Jonnson et al. (2010) have reported nucleotide differences in the Domain II region of the $R$. (B.) microplus sodium channel from pyrethroid resistant populations in Australia. These nucleotide differences in the Australian cattle tick sodium channel gene led to amino acid changes that correlated with pyrethroid resistance. In the case of the Morgan et al. (2009) report, the amino acid change is from leucine to isoleucine, while the change in the Jonsson et al. (2010) report is a glycine to valine.

The phenotypic effect of each of the three mutations differs significantly. The Domain III phenylalanine to isoleucine change confers a very high level of resistance to permethrin, cypermethrin, and flumethrin in the homozygous state as seen in the highly acaricide-selected Mexican Corrales strain (>1000-fold, MILLER et al., 1999). The Domain II mutations are reported to convey lesser levels of resistance. The leucine to isoleucine change reported by Morgan et al. (2009) conveys moderate levels (100-400-fold estimates) of resistance to permethrin, cypermethrin, and flumethrin, while the glycine to valine change was flumethrin resistance-specific and seemed to provide lower levels of resistance (JONSSON et al., 2010). Thus there are at least three target site mechanisms for pyrethroid resistance in $R$. (B.) microplus. The Domain III mutation seems to be localized to North America, the Morgan et al. (2009) mutation was discovered in Australia but has been seen outside of Australia (Table 1) while the Jonsson et al. (2010) mutation is only reported in Australia. The discovery of the Morgan et al. (2009) mutation allowed a successful conclusion to mechanistic studies of the multiply-resistant Brazilian Santa Luiza strain of $R$. (B.) microplus. Li et al. (2008) had reported genetic and synergist studies on the 93-fold permethrin resistance of Santa Luiza. Metabolic resistance was ruled out by the lack of significant synergism of pyrethroid resistance by PBO, DEM, or TPP. Molecular studies did not find the Domain III sodium channel mutation of Guerrero et al. (2001), thus suggesting a novel sodium channel mutation was present in the Santa Luiza strain. We have now confirmed that Santa Luiza contains the Morgan et al. (2009) Domain II mutation and this likely leads to the permethrin resistance phenotype of this Brazilian strain (F. GUERRERO, unpublished data).

The molecular aspects of metabolic resistance are not yet well-defined in $R$. (B.) microplus. While metabolic resistance has been generally attributed to the cytochrome P450s, esterases, and 
Table 1. Pyrethroid resistance sodium channel mutation diagnostic assay results ${ }^{1}$.

\begin{tabular}{|c|c|c|c|c|c|}
\hline \multirow[t]{2}{*}{ Country } & \multirow{2}{*}{$\begin{array}{c}\text { Populations } \\
\text { number }\end{array}$} & \multirow{2}{*}{$\begin{array}{c}\text { Larvae } \\
\text { number }\end{array}$} & \multicolumn{3}{|c|}{ Percentage of mutant larvae ${ }^{2}$} \\
\hline & & & Morgan et al. (2009) & Jonsson et al. (2010) & Guerrero et al. (2001) \\
\hline Brazil & 2 & 27 & 96 & 0 & 0 \\
\hline Argentina & 8 & 133 & 76 & 0 & 0 \\
\hline Mexico & 2 & 36 & 0 & 0 & 100 \\
\hline South Africa & 4 & 69 & 26 & 0 & 0 \\
\hline Australia & 1 & 17 & 100 & 0 & 0 \\
\hline
\end{tabular}

${ }^{1}$ Data from PhD research of Léonore Lovis. ${ }^{2}$ Percentage calculation includes larvae that were either heterozygous or homozygous for the indicated mutation.

glutathione S-transferases, each of these are large gene families in the cattle tick with 115,81 , and 39 individual members, respectively (BELLGARD et al., 2012). As knowledge of genetics and genomics of arthropods and the cattle tick advances, it will become possible to specify a gene-mediated metabolic resistance mechanism as has been done for glutathione S-transferase-based DDT resistance in Anopheles gambiae (RANSON et al., 2001) and cytochrome P450based pyrethroid resistance in Musca domestica (TOMITA et al., 1995). Biochemical synergist studies are often used to determine if metabolic resistance mechanisms are present in resistant populations of $R$. (B.) microplus and these are useful. As noted previously, biochemical synergists can only serve as a guide for determination of the mechanism of metabolic resistance. Nevertheless, several $R$. (B.) microplus populations have been examined by synergist studies and metabolic resistance identified. Generally, where target site- and metabolism-based pyrethroid resistance coexists, the target site resistance plays the major role in product failure. However, in some cases metabolic resistance is a major mechanism. For example, studies with PBO and TPP showed the Mexican Coatzacoalcos population of $R$. (B.) microplus had a significant metabolic resistance component within the population's overall 166-, 57-, and 16-fold resistance to permethrin, cypermethrin, and flumethrin, respectively (MILLER et al., 1999). Protein and molecular studies showed only a low percentage of individuals from Coatzacoalcos (8\%) had a single copy of the Domain III sodium channel target site mutation (GUERRERO et al., 2001). However, Coatzacoalcos overproduced a specific esterase, designated CzEst9, that hydrolyzed permethrin (JAMROZ et al., 2000; PRUETT et al., 2002). Baffi et al. (2007, 2008) later reported this esterase played a major role in pyrethroid resistant $R$. (B.) microplus ticks from Mato Grosso, Brazil. Synergist studies with PBO have indicated that cytochrome $\mathrm{P} 450$ s play a role in pyrethroid resistance mechanisms in $R$. (B.) microplus from Mexico (MILLER et al., 1999), but molecular studies have not been reported, and, with PBO's lack of complete specificity towards the cytochrome P450 family, a mechanism cannot be attributed to a specific P450. Finally, although a number of glutathione S-transferases have been identified in $R$. (B.) microplus (BELLGARD et al., 2012), a significant involvement with pyrethroid resistance mechanisms has yet to be reported.

\section{Organophosphate Resistance}

Organophosphates and carbamates target the acetylcholinesterase protein. Although bioassay and synergist studies have been used to provide evidence regarding resistance mechanisms in various $R$. (B.) microplus populations, specific mechanisms have not been identified. There is uncertainty about the identity of the transcript encoding the acetylcholinesterase that is functionally relevant for acaricide resistance in $R$. (B.) microplus. In fact, more than one acetylcholinesterase might be involved in acaricide responses (BAFFI et al., 2008; TEMEYER et al., 2010). Seven contigs with significant sequence similarity to acetylcholinesterase were reported in the most recent $R$. (B.) microplus transcriptome (BELLGARD et al., 2012). Temeyer et al. (2010) expressed three acetylcholinesteraselike transcripts isolated from two organophosphate resistant and one organophosphate susceptible strain of $R$. (B.) microplus and showed that variant alleles existed among individuals in the strain that showed differential response to organophosphate. These authors concluded that "phenotypic resistance to OPs may be complex and multigenic in character". Unfortunately, no specific mutations in acetylcholinesterase have been correlated to organophosphate resistance in field populations, despite considerable effort to find mutations (F. GUERRERO, unpublished data). The concept of multiple forms of acetylcholinesterase in $R$. (B.) microplus was noted as far back as 1972 (NOLAN et al., 1972) where five forms of this enzyme were purified by electrophoretic and verified by biochemical methods. The uncertainty about the specific acetylcholinesterase targeted by organophosphates or mutations that affect the acaricide-target site interaction has prevented the identification of specific target site-mediated resistance mechanisms in $R$. (B.) microplus. Earlier, biochemical kinetic and inhibition studies of acetylcholinesterase in $R$. (B.) microplus had attributed organophosphate resistance in the Mexican Tuxpan, Tuxtla, San Roman, and Caporal strains (WRIGHT; AHRENS, 1988; PRUETT, 2002) and the Argentinian G Goya strain (REICH et al., 1978) to target site insensitivity. More recently, the attribution of resistance to a target site mechanism has sometimes been through the absence of significant effects on toxicity in the presence of synergists such as PBO, TPP, or DEM (LI et al., 2003). In this case, the absence of synergism indicated a lack of metabolic resistance, leading to an inference that target site resistance must be present. In an interesting study, Baffi et al. (2008) reported that a malathion resistant Brazilian strain of $R$. (B.) microplus seemed to have increased amounts of acetylcholinesterase compared to malathion susceptible strains. Thus a target site gene amplification or mutations within the gene promoter region might be the specific resistance mechanism.

Metabolic mechanisms play a role in $R$. (B.) microplus organophosphate resistance, though generally reported in the 
presence of target site resistance. Bull and Ahrens (1988) reported coumaphos metabolism, likely through an esterase-based hydrolysis, was a component of the Tuxpan and Tuxtla Mexican $R$. (B.) microplus populations which were also shown to possess a target site-mediated resistance to organophosphates (WRIGHT; AHRENS, 1988). Jamroz et al. (2000) used biochemical analyses to quantify the esterase-based metabolic mechanisms of organophosphate resistance in the Mexican Tuxpan, Coatzacoalcos, and Corrales strains of $R$. (B.) microplus. A carboxylesterase, termed Est10, was found to be more abundant in the coumaphos resistant Tuxpan strain, so perhaps this esterase plays a significant role in this strain's metabolic resistance. Villarino et al. (2003) detected esterase-based metabolic resistance to organophosphates in the integument of adult female $R$. (B.) microplus. Li et al. (2003) reported evidence that a cytochrome $\mathrm{P} 450$-mediated coumaphos resistance was a significant mechanism in four coumaphos resistant Mexican populations of $R$. (B.) microplus. Interestingly, their PBO synergist studies did not show a P450-mediated resistance mechanism for diazinon in the diazinon resistant Tuxpan and San Roman strains. The coumaphos resistant Mexican San Roman strain showed increased expression of a cytochrome P450-like transcript following treatment with low doses of coumaphos, perhaps playing a role in the metabolic resistance mechanism of that strain (GUERRERO et al., 2007). A coumaphos susceptible strain also showed induction of the cytochrome P450-like transcript upon treatment with coumaphos, but the response of the resistant strain was more robust indicating a greater capacity to respond to the acaricide treatment. As is the case for target site organophosphate resistance, the metabolic mechanisms are not simple to define at the molecular level, although the advent of the $R$. (B.) microplus transcriptome database (BELLGARD et al., 2012) brings this closer to feasibility. The molecular analysis by Saldivar et al. (2008) reported the first evidence for the involvement of a specific glutathione $S$-transferase in $R$. (B.) microplus acaricide resistance (although see below for resistance in Pesqueria strain). The Mexican multiply-resistant San Alfonso strain showed 2-, 91-, and 600-fold resistance to coumaphos, permethrin, and amitraz, respectively. When treated with a low level dose of coumaphos (lethal to approximately $8 \%$ of the individuals), the expression of a specific transcript, TC9004, was increased over 5-fold. When translated, the protein encoded by transcript TC9004, which is from the BmiGI Version 2 gene index of $R$. (B.) microplus (http://compbio.dfci.harvard.edu/cgibin/tgi/gimain.pl?gudb=b_microplus), showed high amino acid sequence similarity to glutathione $S$-transferase.

\section{Resistance Mechanisms to Other Acaricides}

The target site of amitraz has not been definitively identified, although candidates such as monoamine oxidase, octopamine receptor, and alpha-2-adrenceptors have been proposed (JONSSON; HOPE, 2007). The lack of information hampers the development of assays for and identification of target site-based resistance and no resistance-associated mutations in any of the proposed targets of amitraz activity have been reported. Synergist studies with PBO, TPP, and DEM, showed metabolic resistance played a role in amitraz resistance of Mexican strains of $R$. (B.) microplus (LI et al., 2004). Fragozo-Sanchez et al. (2011) suggested that resistance to amitraz is controlled by a recessive inheritance, also it seems that more than one gene are involved in this process. Target site resistance was proposed as the major resistance mechanism in the Brazilian Santa Luiza $R$. (B.) microplus strain by these researchers, although no direct evidence for target site resistance was presented. The Mexican Pesqueria strain was found to be resistant to both diazinon and amitraz, and DEM synergized the toxicities of both chemicals, indicating possible involvement of glutathione $S$-transferases in metabolic resistance to both amitraz and diazinon in this strain.

Fipronil acts on both the 4-aminobutyric acid (GABA)-gated chloride channel and the glutamate-gated chloride channel (ZHAO et al., 2004). This activity on dual targets probably plays a role in delaying or preventing the buildup of high levels of resistance. However, one of these targets is shared with the cyclodiene class of pesticides and low levels of fipronil resistance can be associated with resistance to dieldrin in Drosophila melanogaster (BLOOMQUIST, 1994). Fipronil resistance has been documented in field populations of $R$. (B.) microplus in Uruguay (CUORE et al., 2007; CASTROJANER et al., 2010a, 2011) and Brazil (CASTRO-JANER et al., 2010b), although mechanistic studies were not reported.

Macrocyclic lactones are increasingly being used for cattle tick control and the target site for this class of molecules are also believed to be the GABA- and glutamate-gated chloride channels. Resistance has been reported in Brazil (MARTINS; FURLONG, 2001; KLAFKE et al., 2006, 2012) and Mexico (PEREZCOGOLLO et al., 2010), but studies of resistance mechanisms are just beginning. Because fipronil and the macrocyclic lactones both are believed to act on the glutamate-gated chloride channel and the 4-aminobutyric acid (GABA)-gated chloride channel, the possibility of cross resistance must be considered. Castro-Janer et al. (2011) observed that $R$. (B.) microplus populations that were treated with ivermectin but never treated with fipronil were susceptible to fipronil and tick populations that were resistant to fipronil were susceptible to ivermectin. This indicates the molecular site of action of fipronil and ivermectin are not identical and cross resistance was not detected in Uruguay.

As discussed above, the molecular target sites of a number of acaricidal compounds have yet to be elucidated and characterized. The use of molecular biology and genomics to understand acaricide resistance in $R$. (B.) microplus will play a major role in the comprehension of the molecular mechanisms of resistance. In addition, there is currently very limited molecular information on detoxification genes associated with metabolic resistance, although their importance has been highlighted by numerous biochemical studies in mites and ticks (VAN LEEUWEN, et al., 2010).

\section{Conclusion}

The resistance mechanisms for pyrethroids that act in the cattle tick are beginning to be understood at the molecular level. There is a basic understanding of metabolic mechanisms supporting organophosphate resistance in cattle ticks, however, target site resistance appears complex. Very little is known about 
the resistance mechanisms that are active in amitraz, fipronil, and macrocyclic lactone resistant cattle ticks. Further studies are needed to address these deficiencies in the basic knowledge of cattle tick acaricide resistance. There is a general consensus that advances in tick genomics will accelerate the development of new molecular targets and new diagnostic tools for acaricide resistance detection, which in turn can improve strategies for tick control.

\section{Acknowledgements}

We thank Deanna Bodine for technical help with sodium channel mutation assays and Drs. Andrew Li and Robert Miller of their review of the manuscript. FDG acknowledges funding support from the USDA-ARS Knipling Bushland US Livestock Insect Research Laboratory CRIS Project Number 6205-32000031-00. USDA is an equal opportunity provider and employer.

\section{References}

Andreotti R, Guerrero FD, Soares MA, Barros JC, Miller RJ, Pérez de León AA. Acaricide resistance of Rhipicephalus (Boophilus) microplus in State of Mato Grosso do Sul, Brazil. Rev Bras Parasitol Vet 2011; 20(2): 127-133. http://dx.doi.org/10.1590/S1984-29612011000200007

Baffi MA, De Souza GR, Vieira CU, De Sousa CS, Gourlart LR, Bonetti AM. Identification of point mutations in a putative carboxylesterase and their association with acaricide resistance in Rhipicephalus (Boophilus) microplus (Acari: Ixodidae). Vet Parasitol 2007; 148(3-4): 301-309. PMid:17643821. http://dx.doi.org/10.1016/j.vetpar.2007.06.016

Baffi MA, De Souza GR, De Sousa CS, Ceron CR, Bonetti AM. Esterase enzymes involved in pyrethroid and organophosphate resistance in a Brazilian population of Riphicephallus (Boophilus) microplus (Acari: Ixodidae). Mol Biochem Parasitol 2008; 160(1): 70-73. PMid:18472171. http://dx.doi.org/10.1016/j.molbiopara.2008.03.009

Bellgard MI, Moolhuijzen PM, Guerrero FD, Schibeci D, RodriguezValle M, Peterson DG, et al. CattleTickBase: An integrated Internetbased bioinformatics resource for Rhipicephalus (Boophilus) microplus. Int J Parasitol 2012; 42(2): 161-169. PMid:22178513. http://dx.doi. org/10.1016/j.ijpara.2011.11.006

Bloomquist JR. Cyclodiene resistance at the insect GABA receptor/ chloride channel complex confers broad cross resistance to convulsants and experimental phenylpyrazole insecticides. Arch Insect Biochem Physiol 1994; 26(1): 69-79. PMid:8054658. http://dx.doi.org/10.1002/ arch.940260106

Bull DL, Ahrens EH. Metabolism of coumaphos in susceptible and resistant strains of Boophilus microplus (Acari: Ixodidae). J Med Entomol 1988; 25(2): 94-98. PMid:3351878.

Castro-Janer E, Rifran L, Gonzalez P, Piaggio J, Gil A, Schumaker TTS. Rhipicephalus (Boophilus) microplus (Acari: Ixodidae) resistance to fipronil in Uruguay evaluated by in vitro bioassays. Vet Parasitol 2010a; 169(1-2): 172-177. PMid:20056329. http://dx.doi.org/10.1016/j. vetpar.2009.12.017

Castro-Janer E, Martins JR, Mendez MC, Namindome A, Klafke GM, Schumaker TTS. Diagnoses of fipronil resistance in Brazilian cattle ticks (Rhipicephalus (Boophilus) microplus) using in vitro larval bioassays. Vet Parasitol 2010b; 173(3-4): 300-306. PMid:20688434. http://dx.doi. org/10.1016/j.vetpar.2010.06.036
Castro-Janer E, Rifran L, Gonzalez P, Niell C, Piaggio J, Gil A, et al. Determination of the susceptibility of Rhipicephalus (Boophilus) microplus (Acari: Ixodidae) to ivermectin and fipronil by Larval Immersion Test (LIT) in Uruguay. Vet Parasitol 2011; 178(1-2): 148-155. PMid:21277092. http://dx.doi.org/10.1016/j.vetpar.2010.12.035

Cuore U, Trelles A, Sanchis J, Gayo V, Solari MA. Primer diagnóstico de resistencia al fipronil en la garrapata común del ganado Boophilus microplus. Vet (Montevideo) 2007; 42: 35-41.

Fragoso-Sanchez H, Garcia-Vazquez Z, Tapia-Perez G, Ortiz-Najera A, Rosario-Cruz R, Rodriguez-Vivas I. Response of Mexican Rhipicephalus (Boophilus) microplus ticks to selection by amitraz and genetic analysis of attained resistance. J Entomol 2011; 8(3): 218-228. http://dx.doi. org/10.3923/je.2011.218.228

Guerrero FD, Davey RB, Miller RJ. Use of an allele-specific polymerase chain reaction assay to genotype pyrethroid resistant strains of Boophilus microplus (Acari: Ixodidae). J Med Entomol 2001; 38(1): 44-50. PMid:11268690. http://dx.doi.org/10.1603/0022-2585-38.1.44

Guerrero FD, Bendele KG, Chen AC, Li AY, Miller RJ, Pleasance E, et al. Serial analysis of gene expression in the southern cattle tick following acaricide treatment of larvae from organophosphate resistant and susceptible strains. Insect Mol Biol 2007; 16(1): 49-60. PMid:17257208. http://dx.doi.org/10.1111/j.1365-2583.2007.00699.x

He H, Chen AC, Davey RB, Ivie GW, George JE. Identification of a point mutation in the para-type sodium channel gene from a pyrethroidresistant cattle tick. Biochem Biophys Res Commun 1999; 261(3): 558-561. PMid:10441465. http://dx.doi.org/10.1006/bbrc.1999.1076

Jamroz RC, Guerrero FD, Pruett JH, Oehler DD, Miller RJ. Molecular and biochemical survey of acaricide resistance mechanisms in larvae from Mexican strains of the southern cattle tick, Boophilus microplus. J Insect Physiol 2000; 46(5): 685-695. http://dx.doi.org/10.1016/S00221910(99)00157-2

Jonsson NN, Hope M. Progress in the epidemiology and diagnosis of amitraz resistance in the cattle tick Boophilus microplus. Vet Parasitol 2007; 146(3-4): 193-198. PMid:17448604. http://dx.doi. org/10.1016/j.vetpar.2007.03.006

Jonsson NN, Cutullè C, Corley SW, Seddon JM. Identification of a mutation in the para-sodium channel gene of the cattle tick Rhipicephalus (Boophilus) microplus associated with resistance to flumethrin but not to cypermethrin. Int J Parasitol 2010; 40(14): 1659-1664. PMid:20708620. http://dx.doi.org/10.1016/j.ijpara.2010.07.006

Klafke GM, Sabatini GA, Albuquerque TA, Martins JR, Kemp DH, Miller RJ, et al. Larval immersion tests with ivermectin in populations of the cattle tick Rhipicephalus (Boophilus) microplus (Acari: Ixodidae) from State of Sao Paulo, Brazil. Vet Parasitol 2006; 142(3-4): 386-390. PMid:16904265. http://dx.doi.org/10.1016/j.vetpar.2006.07.001

Klafke GM, Castro-Janer E, Mendes MC, Namindome A, Schumaker, TTS. Applicability of in vitro bioassays for the diagnosis of ivermectin resistance in Rhipicephalus microplus (Acari: Ixodidae). Vet Parasitol 2012; 184(3-4): 212-220. PMid:21978742. http://dx.doi. org/10.1016/j.vetpar.2011.09.018

Li AY, Davey RB, Miller RJ, George JE. Resistance to coumaphos and diazinon in Boophilus microplus (Acari: Ixodidae) and evidence for the involvement of an oxidative detoxification mechanism. $J$ Med Entomol 2003; 40(4): 482-490. PMid:14680115. http://dx.doi. org/10.1603/0022-2585-40.4.482

Li AY, Davey RB, Miller RJ, George JE. Detection and characterization of amitraz resistance in the Southern cattle tick, Boophilus microplus (Acari: 
Ixodidae). J Med Entomol2004; 41(2): 193-200. PMid:15061278. http:// dx.doi.org/10.1603/0022-2585-41.2.193

Li AY, Davey RB, Miller RJ, Guerrero FB, George JE. Genetics and Mechanisms of Permethrin Resistance in the Santa Luiza Strain of Boophilus microplus (Acari: Ixodidae). J Med Entomol 2008; 45(3): 427-438. http:// dx.doi.org/10.1603/0022-2585(2008)45[427:GAMOPR]2.0.CO;2

Martins JR, Furlong J. Avermectin resistance of Boophilus microplus in Brazil. Vet Rec 2001; 149(2): 64.

Mckosker P J. Global aspects of the management and control of ticks of veterinary importance. In: Rodriguez J. (Ed). Recent Advances in Acarology. London: Academic Press; 1979. p. 45-53.

Miller RJ, Davey RJ, George JE. Characterization of pyrethroid resistance and susceptibility to coumaphos in Mexican Boophilus microplus (Acari: Ixodidae). J Med Entomol 1999; 36(5): 533-538. PMid:10534945.

Miller RJ, Davey RB, George JE. First report of permethrin-resistant Boophilus microplus (Acari: Ixodidae) collected within the United States. J Med Entomol 2007; 44(2): 308-315. http://dx.doi.org/10.1603/00222585(2007)44[308:FROPBM]2.0.CO;2

Morgan JAT, Corley SW, Jackson LA, Lew-Tabor AE, Moolhuijzen PM, Jonsson NN. Identification of a mutation in the para-sodium channel gene of the cattle tick Rhipicephalus (Boophilus) microplus associated with resistance to synthetic pyrethroid acaricides. Int J Parasitol 2009; 39(7): 775-779. http://dx.doi.org/10.1016/j. ijpara.2008.12.006

Nolan J, Schnitzerling HJ, Schuntner CA. Multiple forms of acetylcholinesterase from resistant and susceptible strains of the cattle tick, Boophilus microplus (Can.). Pestic Biochem Physiol 1972; 2(1): 85-94. http://dx.doi.org/10.1016/0048-3575(72)90010-7

Noppun V, Saito T, Miyata T. Cuticular penetration of $S$-fenvalerate in fenvalerate-resistant and susceptible strains of the diamondback moth, Plutella xylostella (L.). Pestic Biochem Physiol 1989; 33(1): 83-87. http:// dx.doi.org/10.1016/0048-3575(89)90079-5

Perez-Cogollo LC, Rodriguez-Vivas RI, Ramirez-Cruz GT, Miller RJ. First report of the cattle tick Rhipicephalus microplus resistant to ivermectin in Mexico. Vet Parasitol 2010; 168(1-2): 165-169. PMid:19951828. http://dx.doi.org/10.1016/j.vetpar.2009.10.021

Pruett JH. Comparative inhibition kinetics for acetylcholinesterases extracted from organophosphate resistant and susceptible strains of Boophilus microplus (Acari: Ixodidae). J Econ Entomol 2002; 95(6): 1239-1244. PMid:12539837. http://dx.doi.org/10.1603/0022-049395.6 .1239

Pruett JH, Guerrero FD, Hernandez R. Isolation and identification of an esterase from a Mexican strain of Boophilus microplus (Acari: Ixodidae). JEcon Entomol 2002; 95(5): 1001-1007. PMid:12403427. http://dx.doi. org/10.1603/0022-0493-95.5.1001

Ranson H, Rossiter L, Ortelli F, Jensen B, Wang X, Roth CW, et al. Identification of a novel class of insect glutathione $\mathrm{S}$-transferases involved in resistance to DDT in the malaria vector Anopheles gambiae. Biochem J 2001; 359(2): 295-304. PMid:11583575. PMCid:1222147. http:// dx.doi.org/10.1042/0264-6021:3590295

Reich CI, Grillo Torrado JM, Pérez Arrieta A, Zorzópulos J. Boophilus microplus: Strain differences of the cholinesterase system. Exp Parasitol 1978; 44(1): 50-55. http://dx.doi.org/10.1016/00144894(78)90079-6
Rosario-Cruz R, Guerrero FD, Miller RJ, Rodriguez-Vivas RI, Domínguez-Garcia DI, Cornel AJ, et al. Roles played by esterase activity and by a sodium channel mutation involved in pyrethroid resistance in populations of Boophilus microplus (Acari: Ixodidae) collected from Yucatán, Mexico. J Med Entomol 2005; 42(6): 1020-1025. http://dx.doi. org/10.1603/0022-2585(2005)042[1020:RPBEAA]2.0.CO;2

Rosario-Cruz R, Guerrero FD, Miller RJ, Rodriguez-Vivas RI, Tijerina M, Domínguez-Garcia DI, et al. Molecular survey of pyrethroid resistance mechanisms in Mexican field populations of Rhipicephalus (Boophilus) microplus. Parasitol Res 2009; 105(4): 1145-1153. PMid:19565267. PMCid:2729983. http://dx.doi.org/10.1007/s00436-009-1539-1

Saldivar L, Guerrero FD, Miller RJ, Bendele KG, Gondro C, Brayton KA. Microarray analysis of acaricide-inducible gene expression in the southern cattle tick, Rhipicephalus (Boophilus) microplus. Insect Mol Biol2008; 17(6): 597-606. PMid:18834453. http://dx.doi.org/10.1111/ j.1365-2583.2008.00831.x

Schnitzerling HJ, Nolan J, Hughes S. Toxicology and metabolism of some synthetic pyrethroids in larvae of susceptible and resistant strains of the cattle tick Boophilus microplus (Can.). Pestic Sci 1983; 14(1): 64-72. http://dx.doi.org/10.1002/ps.2780140110

Soderlund DM, Knipple DC. The molecular biology of knockdown resistance to pyrethroid insecticides. Insect Biochem Mol Biol 2003; 33(6): 563-577. http://dx.doi.org/10.1016/S09651748(03)00023-7

Temeyer KB, Pruett JH, Olafson PU. Baculovirus expression, biochemical characterization and organophosphate sensitivity of $\mathrm{rBmAChE1}$, rBmAChE2, and rBmAChE3 of Rhipicephalus (Boophilus) microplus. Vet Parasitol 2010; 172(1-2): 114-121. PMid:20451328. http://dx.doi. org/10.1016/j.vetpar.2010.04.016

Tomita T, Liu N, Smith FF, Sridhar P, Scott JG. Molecular mechanisms involved in increased expression of a cytochrome $\mathrm{P} 450$ responsible for pyrethroid resistance in the housefly, Musca domestica. Insect Mol Biol 1995; 4(3): 135-140. PMid:8589839. http://dx.doi. org/10.1111/j.1365-2583.1995.tb00018.x

Van Leeuwen T, Vontas J, Tsagkarakou A, Dermauw W, Tirry L. Acaricide resistance mechanisms in the two-spotted spider mite Tetranychus urticae and other important Acari: A review. Insect Biochem Mol Biol 2010; 40(8): 563-572. PMid:20685616. http://dx.doi. org/10.1016/j.ibmb.2010.05.008

Villarino MA, Waghela SD, Wagner GG. Biochemical detection of esterases in the adult female integument of organophosphate-resistant Boophilus microplus (Acari: Ixodidae). J Med Entomol 2003; 40(1): 52-57. PMid:12597652. http://dx.doi.org/10.1603/0022-2585-40.1.52

Wright FC, Ahrens EH. Cholinesterase insensitivity: A mechanism of resistance in Mexican strains of Boophilus microplus (Acari: Ixodidae) against coumaphos. J Med Entomol 1988; 25(4): 234-239. PMid:3404542.

Young SJ, Gunning RV, Moores GD. The effect of piperonyl butoxide on pyrethroid-resistance associated esterases in Helicoverpa armigera (Hübner) (Lepidoptera: Noctuidae). Pest Manag Sci 2005; 61(4): 397-401. PMid:15605351. http://dx.doi.org/10.1002/ps.996

Zhao X, Yeh JZ, Salgado VL, Narahashi T. Fipronil is a potent open channel blocker of glutamate-activated chloride channels in cockroach neurons. J Pharmacol Exp Ther 2004; 310(1): 192-201. PMid:15014137. http://dx.doi.org/10.1124/jpet.104.065516 